\title{
AKTA NOTARIS (AKTA OTENTIK) \\ SEBAGAI ALAT BUKTI DALAM PERISTIWA HUKUM PERDATA
}

\author{
I Ketut Tjukup ${ }^{1}$, I Wayan Bela Siki Layang ${ }^{2}$, Nyoman A. Martana ${ }^{3}$, \\ I Ketut Markeling ${ }^{4}$, Nyoman Satyayudha Dananjaya ${ }^{5}$, I Putu Rasmadi Arsha \\ Putra $^{6}$, Komang Widiana Purnawan ${ }^{7}$, Made Diah Sekar Mayang Sari ${ }^{8}$, \\ Ketut Nihan Pundari ${ }^{9}$ dan Putu Ayu Ratih Tribuana ${ }^{10}$
}

\begin{abstract}
Notary is one of professions lawful services to public, which has responsibilities related with authentic attesting instruments, such as, letters,certificates, or documents made by him/her in written form concerning various lawful actions

Departing from the circumstances as preventive measures of prevention needs to be premature given information about the notarial deed (deed authentic) as evidence in the event of civil law in order to later villagers in any transaction in a very large amount in order to carry out the agreement in front notary officials.

The fact that occurs in the community, some of them are less aware of the importance of a document as evidence that an agreement between the parties is done with a sense of mutual trust and made orally, but there are also some people who understand the importance of making a document as evidence that the deal is made in writing, that it will be presented as a means of evidence.
\end{abstract}

Keywords: Notarial deed, Evidence

${ }^{1}$ Dosen pada Bagian Hukum Acara Fakultas Hukum Universitas Udayana.

${ }^{2}$ Dosen pada Bagian Hukum Acara Fakultas Hukum Universitas Udayana.

${ }^{3}$ Dosen pada Bagian Hukum Acara Fakultas Hukum Universitas Udayana.

${ }^{4}$ Dosen pada Bagian Hukum Perdata Fakultas Hukum Universitas Udayana.

${ }^{5}$ Dosen pada Bagian Hukum Acara Fakultas Hukum Universitas Udayana.

${ }^{6}$ Dosen pada Bagian Acara Fakultas Hukum Universitas Udayana.

${ }^{7}$ Dosen pada Bagian Hukum Internasional Fakultas Hukum Universitas Udayana.

${ }^{8}$ Dosen pada Bagian Hukum Acara Fakultas Hukum Universitas Udayana.

${ }^{9}$ Mahasiswa S2 Kenotariatan Universitas Udayana

${ }^{10}$ Mahasiswa S2 Kenotariatan Universitas Udayana 


\section{PENDAhuluan}

\subsection{Latar Belakang}

Dalam Undang-Undang Dasar

Negara Republik Indonesia Tahun 1945 mengatur dengan tegas, bahwa Indonesia adalah negara hukum. Prinsip dari negara hukum adalah menjamin kepastian, ketertiban dan perlindungan hukum yang berintikan kebenaran dan keadilan. Kepastian, ketertiban dan perlindungan hukum menuntut adanya alat bukti yang menentukan dengan jelas hak dan kewajiban orang atau badan hukum sebagai subjek hukum di dalam masyarakat. ${ }^{1}$

Untuk menjamin kepastian, ketertiban dan perlindungan hukum mengenai hak-hak pribadi seseorang maka diaturlah hak-hak tersebut kedalam Hukum Perdata. Hukum Perdata sebagai hukum materiilnya dan Hukum Acara Peradilan Perdata sebagai hukum formilnya. Fungsi Hukum Acara Perdata adalah peraturan hukum yang mengatur bagaimana cara menjamin ditaatinya hukum perdata materiil dengan perantara hakim. Hukum Acara mengatur bagaimana cara seseorang mengajukan tuntutan hak, memeriksa, serta memutusnya dan melaksanakan putusannya, hal ini untuk mencegah main hakim sendiri atau eigenrechting. ${ }^{2}$ Dalam mengajukan tuntutan hak seseorang harus cukup bukti agar tuntutannya tidak sia-sia. Dalam Hukum Acara Perdata dikenal beberapa alat bukti, sebagaimana telah

1 Jimly Asshiddiqie dan Ali Safa'at, 2006, Teori Hans Kelsen Tentang Hukum, Setjen dan Kepaniteraan Mahkamah Konstitusi Republik Indonesia, Jakarta, h. 61.

2 Sudikno Mertokusumo, 2006, Hukum Acara Perdata Indonesia, Liberty, Yogyakarta, h. 2 ditentukan dalam Pasal 1866 KUH Perdata yang meliputi, bukti tulisan, bukti dengan saksisaksi, persangkaanpersangkaan, pengakuan, dan sumpah.

Pembuktian dengan tulisan dilakukan dengan akta otentik maupun dengan akta di bawah tangan. Akta adalah suatu tulisan yang memang dengan sengaja dibuat untuk dapat dijadikan bukti bila ada suatu peristiwa dan ditanda tangani. ${ }^{3}$ Akta otentik adalah akta yang dibuat dihadapan pejabat (notaries, sedangkan akta dibawah tangan adalah kesepakatan para pihak yang melakukan perjanjian. Akta memiliki 2 (dua) fungsi penting, yaitu fungsi formil (formalitas causa) dan fungsi alat bukti (probationis causa). Fungsi formil (formalitas causa) berarti bahwa untuk lengkapnya atau sempurnanya (bukan untuk sahnya) suatu perbuatan hukum haruslah dibuat suatu akta. Fungsi alat bukti (probationis causa) bahwa akta itu dibuat sejak semula dengan sengaja untuk pembuktian di kemudian hari, sifat tertulisnya suatu perjanjian dalam bentuk akta itu tidak membuat sahnya perjanjian, tetapi hanyalah agar dapat digunakan sebagai alat bukti dikemudian hari. ${ }^{4}$

Notaris sebagai pejabat umum yang membuat akta autentik, tercantum pada Pasal 1 angka 1 Undang-Undang Nomor 2 Tahun 2014 mengatur bahwa notaris adalah pejabat umum yang berwenang untuk membuat akta autentik dan memiliki kewenangan lainnya sebagai dimaksud dalam undangundang ini atau

3 R. Subekti, 2001, Hukum Pembuktian, Pradinya Paramita, Jakarta , h. 48

Sudikno Mertokusumo,1999, Mengenal Hukum suatu Pengantar, Liberty, Yogyakarta h.121-122 
berdasarkan undang-undang lainnya. Selanjutnya Pasal 1 angka 7 UndangUndang Nomor 2 Tahun 2014 mengatur bahwa akta notaris yang selanjutnya disebut akta adalah akta autentik yang dibuat oleh atau di hadapan notaris menurut bentuk dan tata cara yang ditetapkan dalam undang-undang ini.

Kewenangan notaris dalam membuat akta autentik, harus berdasarkan permintaan dari para penghadap. Notaris wajib mendengarkan keterangan atau pernyataan para pihak tanpa memihak kepada salah satu pihak, kemudian keterangan atau pernyataan tersebut dituangkan kedalam akta notaris yang merupakan keinginan dari para pihak. Selanjutnya setelah akta tersebut dibacakan di hadapan para pihak dan disetujui oleh para pihak, kemudian para pihak menandatangani akta tersebut di hadapan notaris dan akta tersebut harus sesuai dengan Pasal 38 Undang-Undang Nomor 2 Tahun 2014.

Pasal 1868 Kitab Undang-Undang Hukum Perdata menyebutkan bahwa, suatu akta autentik ialah suatu akta yang di dalam bentuk yang ditentukan oleh undang-undang, dibuat oleh atau di hadapan pegawaipegawai umum yang berkuasa untuk itu di tempat di mana akta dibuatnya. Notaris dalam hal ini kemudian menyimpan akta tersebut sebagai minuta akta yang merupakan bagian dari protokol notaris.

Otensitas akta notaries diatur dalam Pasal 1868 KUH Perdata sebagai dasar legalitas eksistensi akta Notaris. Pasal 1868 KUH Perdata hanya merumuskan arti kata otentik dan tidak menyebutkan siapa pejabat umum itu, bagaimana bentuk aktanya dan kapan Pejabat Umum itu berwenang. Secara implisit pasal ini menghendaki adanya suatu Undang-undang yang mengatur tentang Pejabat Umum dan bentuk aktanya. Undang-undang Nomor 30 Tahun 2004 tentang Jabatan Notaris atau biasa disebut dengan UUJN merupakan satusatunya Undang-undang organik yang mengatur Notaris sebagai Pejabat Umum dan bentuk akta Notaris. Notaris menurut UUJN adalah pejabat umum yang berwenang untuk membuat akta otentik dan kewenangan lainnya sebagaimana dimaksud dalam Undangundang. Notaris merupakan perpanjangan tangan dari Pemerintah dalam hal ini negara. Negara telah memberikan kepercayaan kepada Notaris untuk menjalankan sebagian urusan atau tugas negara, khususnya dalam bidang hukum perdata.

Akta otentik merupakan alat bukti yang sempurna sebagaimana diatur dalam pasal 1870 Kitab Undang-undang Hukum Perdata, ia memberikan diantara para pihak termasuk para ahli warisnya atau orang yang mendapat hak dari para pihak itusuatu bukti yang sempurna tentang apa yang diperbuat/dinyatakan dalam akta ini, ini berarti mempunyai kekuatan bukti sedemikian rupa karena dianggap melekatnya pada akta itu sendiri sehingga tidak perlu dibuktikan lagi dan bagi hakim itu merupakan "Bukti wajib" (Verplicht Bewijs), Dengan demikian barang siapa yang menyatakan bahwa akta otentik itu palsu maka ia harus membuktikan tentang kepalsuan akta itu, oleh karena itulah maka akta otentik mempunyai 
kekuatan pembuktian baik lahiriah, formil maupun materiil.

Demikian pentingnya akta otentik dalam hal pembuktian di pengadilan. Namun masyarakat di Indonesia terutama di pedesaan masih kental dengan adat dan kebiasaan, dalam perbuatan hukum yang penting hanya dibuktikan dengan kesaksian dari beberapa orang saksi, biasanya disaksikan oleh tetangga, teman sekampung atupun Kepala Desa. Bahkan dalam perbuatan hukum yang memiliki akibat hukum yang penting, seperti transaksi jual beli atau sewa-menyewa serta mengenai peristiwa penting lainnya dalam lingkungan keluarga, umpamanya pembagian warisan, pengangkatan anak bagi orang yang tidak mempunyai anak sendiri dengan hak untuk mewaris.

Berdasarkan bukti tertulis merupakan alat pembuktian yang penting dalam lalu lintas hukum, baik dalam arti materilnya ialah dengan adanya bukti tertulis, maupun dalam arti formal yang menyangkut kekuatan dari alat pembuktian itu sendiri, maka penulis ingin membahas mengenai pentingnya akta notaries sebagai alat bukti dan hambatannya dalam membuat akta notaris.

\subsection{Rumusan Masalah}

Berdasarkan uraian di atas, permasalahan yang diangkat dalam penulisan jurnal ini adalah sebagai berikut:

1. Apa pentingnya akta notaris sebagai alat bukti dalam hubungan hukum perdata?

2. Bagaimana prosedur pembuatan akta notaris dan hambatan-hambatannya dalam pembuatan akta notaris?

\subsection{Tujuan dan Manfaat}

\section{a. Tujuan}

1. Tujuan Umum

Tujuan yang ingin dicapai adalah mengetahui tingkat kesadaran masyarakat terhadap aturan-aturan hukum yang berlaku tentang kenotariatan.

2. Tujuan khusus

a. Mengetahui dan menganalisis pentingnya akta notaries sebagai alat bukti yang autentik dalam hubungan hukum perdata

b. Memahami dan mengevaluasi prosedur pengurusan akta notaries beserta hambatan-hambatannya.

\section{b. Manfaat}

Pentingnya akta notaris (akta otentik) sebagai bukti dalam peristiwa hukum perdata diharapkan dapat memberikan manfaat teoritis maupun praktis sebagai berikut :

1. Manfaat teoritis

Diharapkan dapat memberikan sumbangan bagi pengembangan ilmu hukum dimasa yang akan datang, serta bermanfaat bagi pengembangan Tri Dharma Perguruan Tinggi, dan dapat memberikan sumbangan bagi pengembangan bagi pengembangan hukum dalam bidang hukum kenotariat.

2. Manfaat praktis

a. Dapat meningkatkan kesadaran hukum dari masyarakat terhadap ketaatan atas aturan-aturan hukum yang berlaku.

b. Dapat memberikan kepastian hukum bila terjadi sengketa dikemudian hari. 
BAB II. PEMBAHASAN

\subsection{Pentingnya Akta Notaris Sebagai Alat} Bukti dalam Hubungan Hukum Perdata

Pasal 1 Undang-Undang Nomor 2 Tahun 2014 tentang Jabatan Notaris menyatakan bahwa Notaris adalah pejabat umum yang berwenang untuk membuat akta otentik dan kewenangan lainnya sebagaimana dimaksud undangundang ini.

Pejabatan umum yang dimaksud adalah Notaris, sehingga aktanya yang dibuat oleh Notaris dalam kedudukannya tersebut memperoleh sifat akta otentik, Akta yang dibuat oleh Notaris mempunyai sifat otentik bukan oleh karena undang-undang menetapkan demikian, tetapi karena akta itu dibuat oleh atau dihadapan pejabat umum hal ini sebagaimana dimaksud dalam Pasal 1868 Kitab Undang-undang Hukum Perdata yang menyatakan "Suatu akta otentik ialah suatu akta yang didalam bentuk yang ditentukan oleh undangundang, dibuat oleh atau dihadapan pegawai-pegawai umum yang berkuasa untuk itu ditempat dimana akta dibuatnya.

Dalam kenyataan yang terjadi dalam masyarakat, sebagian dari mereka kurang menyadari pentingnya suatu dokumen sebagai alat bukti sehingga kesepakatan diantara para pihak cukup dilakukan dengan rasa saling kepercayaan dan dibuat secara lisan, tetapi ada pula sebagian masyarakat yang lebih memahami pentingnya membuat suatu dokumen sebagai alat bukti sehingga kesepakatan-kesepakatan tersebut dibuat dalam bentuk tulisan, yang memang nantinya akan disajikan sebagi alat bukti.
Peristiwa-peristiwa itu dapat berupa peristiwa-peristiwa biasa dalam kehidupan masyarakat itu, seperti pemberian nama kepada anak yang baru lahir, tetapi dapat juga merupakan peristiwa yang mempunyai akibat hukum yang penting, umpamanya dalam transaksi jual beli atau sewa-menyewa serta mengenai peristiwa penting lainnya dalam lingkungan keluarga, umpamanya pembagian warisan, pengangkatan anak bagi orang yang tidak mempunyai anak sendiri dengan hak untuk mewaris. ${ }^{5}$

Sebagian masyarakat sebenarnya sudah mulai sadar akan adanya alat bukti sehingga setiap peristiwa hukum dibuatnya dalam bentuk yang tertulis dari suatu peristiwa penting dengan mencatatnya pada suatu surat dan ditandatangani oleh orang-orang yang berkepentingan dengan disaksikan dua orang saksi atau lebih. Berdasarkan hal tersebut masyarakat menyadari bahwa bukti tertulis merupakan alat pembuktian yang penting dalam lalu lintas hukum, baik dalam artimaterilnya ialah dengan adanya bukti tertulis, maupun dalam arti formal menyangkut kekuatan dari alat pembuktian itu sendiri.

Berbicara mengenai alat bukti, dalam Pasal 164 Herzein Indonesisch Reglement (HIR) jo Pasal 1866 Kitab Undang-Undang Hukum Perdata (KUH Perdata) menyatakan ${ }^{6}$ yang disebut bukti, yaitu :
a. Bukti Surat
b. Bukti Saksi

5 Soegondo Notodirejo, R, 1982, Hukum Notariat Di Indonesia, Rajawali, Jakarta,h.4.

${ }^{6}$ R. Tresna, 1996, Komentar HIR, Pradaya paramita,Jakarta,h.141. 


\section{c. Bukti Sangka \\ d. Pengakuan \\ e. Sumpah}

Semua jenis alat bukti tersebut didalam proses perkara di Pengadilan semuanya adalah penting, namun menurut HIR dan RBg yang menganut asas pembuktian formal, maka disini tampak bahwa bukti surat yang merupakan alat bukti tertulis merupakan hal yang sangat penting didalam pembuktian, kekuatan pembuktian mengenai alat bukti surat ini diserahkan pada kebijaksanaan hakim.

$$
\text { Berdasarkan Pasal } 1868 \text { Kitab }
$$

Undang-undang Hukum Perdata ini, maka dapat diketahui bahwa bentuk akta ada dua yaitu akta yang dibuat oleh Notaris (relaas akta) dan akta yang dibuat di hadapan Notaris (partij akta), Akta yang dibuat oleh Notaris dapat merupakan suatu akta yang memuat relaas atau menguraikan secara otentik suatu tindakan yang dilakukan atau suatu keadaan yang dilihat atau yang disaksikan oleh pembuat akta itu, yakni Notaris sendiri, didalam menjalankan jabatannya sebagi Notaris akta ini disebut juga akta yang dibuat oleh (door) Notaris.

Akta Notaris dapat juga berisikan suatu cerita dari apa yang terjadi, karena perbuatan yang dilakukan oleh pihak lain di hadapan Notaris, artinya yang diterangakan atau yang diceritakan oleh pihak lain terhadap Notaris dalam menjalankan jabatannya dan untuk keperluan mana pihak lain itu sengaja datang dihadapan notaris, agar keterangan atau perbuatan itu di konstantir oleh notaries dalam suatu akta otentik, akta ini disebut pula akta yang dibuat dihadapan (ten overstaan) Notaris.

Akta yang dibuat dengan tidak memenuhi Pasal 1868 Kitab Undangundang Hukum Perdata bukanlah akta otentik atau disebut juga akta dibawah tangan, ada beberapa perbedaan antara akta otentik dan akta yang dibuat dibawah tangan ialah:

1. Akta Otentik merupakan alat bukti yang sempurna sebagaimana diatur dalam pasal 1870 Kitab Undangundang Hukum Perdata, akta ini mempunyai kekuatan bukti sedemikian rupa karena dianggap melekatnya pada akta itu sendiri sehingga tidak perlu dibuktikan lagi dan bagi hakim itu merupakan "Bukti wajib" (Verplicht Bewijs), maka dengan demikian barang siapa yang menyatakan bahwa akta otentik itu palsu maka ia harus membuktikan tentang kepalsuan akta itu, oleh karena itulah maka akta otentik mempunyai kekuatan pembuktian baik lahiriah, formil maupun materiil.

2. Akta dibawah tangan Akta dibawah tangan bagi Hakim merupakan "Bukti Bebas" (VRU Bewijs) karena akta dibawah tangan baru mempunyai kekuatan bukti materiil setelah dibuktikan kekuatan formilnya sedangakan kekuatan pembuktian formilnya baru terjadi, bila pihak-pihak yang bersangkutan mengetahui akan kebenaran isi dan cara pembuatan akta itu, dengan demikian akta dibawah tangan berlainan dengan akta otentik, sebab bilamana satu akta dibawah tangan dinyatakan palsu, maka yang 
menggunakan akta dibawah tangan itu sebagai bukti haruslah membuktikan bahwa akta itu tidak palsu.

Berdasarkan uraian tersebut diatas maka akta yang dibuat secara otentik dengan akta yang dibuat secara dibawah tangan, mempunyai nilai pembuktian suatu akta yang meliputi: ${ }^{7}$

1. Kekuatan Pembuktian Lahir Kekuatan pembuktian lahiriah artinya akta itu sendiri mempunyai kemampuan untuk membuktikan dirinya sendiri sebagai akta otentik; mengingat sejak awal yaitu sejak adanya niat dari pihak-pihak yang berkepentingan untuk membuat atau melahirkan alat bukti, maka sejak saat mempersiapkan kehadirannya itu telah melalui proses sesuai dan memenuhi ketentuan Pasal 1868 Kitab Undang-undang Hukum Perdata Jo undang-undang Nomor 30 Tahun 2004 tentang Jabatan Notaris (atau dahulu staablad 1860 Nomor 3 Reglement of Notaris ambt in Indonesie), Kemampuan atau kekuatan pembuktian lahirlah ini tidak ada pada akta/surat dibawah tangan (Vide Pasal 1875 Kitab Undang-undang Hukum Perdata).

\section{Kekuatan Pembuktian Formiil} Kekuatan Pembuktian Formiil artinya dari akta otentik itu dibuktikan bahwa apa yang dinyatakan dan dicantumkan dalam akta itu adalah benar merupakan uraian kehendak pihak-pihak; itulah kehendak pihakpihak yang dinyatakan dalam akta itu oleh atau dihadapan Pejabat yang berwenang dalam menjalankan jabatannya, Dalam arti formil akta otentik menjamin kebenaran :
a. Tanggal
b. Tanda Tangan
c. Komparan dan
d. Tempat akta dibuat

Dalam arti formil akta Notaris membuktikan kebenaran dari apa yang disaksikan yaitu yang dilihat, didengar dan dialami sendiri oleh Notaris sebagai Pejabat Umum dalam menjalankan jabatannya, Akta dibawah tangan tidak mempunyai kekuatan formil, terkecuali bila si penandatangan dari surat/akta itu mengakui kebenaran tanda tangannya.

3. Kekuatan pembuktian material artinya bahwa secara hukum isi dari akta itu telah membuktikan kebenarannya sebagai yang benar terhadap setiap orang, yang membuat atau menyuruh membuat akta itu sebagai tanda bukti terhadap dirinya, inilah yang dinamakan sebagai "Preuve Preconstituee" artinya akta itu benar mempunyai kekuatan pembuktian materiil, Kekuatan pembuktian inilah yang dimaksud dalam Pasal 1870, 1871 dan 1875 Kitab Undang-undang Hukum perdata, Oleh karena itulah, maka akta otentik itu berlaku sebagai alat bukti sempurna dan mengikat pihakpihak yang membuat akta itu. Dengan demikian siapapun yang membantah kebenaran akta otentik sebagai alat bukti, maka ia harus membuktikan kebalikannya.

${ }^{7}$ Ibid, h. 74 
a. Prosedur Pembuatan Akta Notaris dan

Hambatan-hambatannya

dalam

Pembuatan Akta Notaris

Akta Otentik adalah akta yang dibuat oleh atau dihadapan pejabat yang diberi wewenang untuk itu oleh penguasa, menurut ketentuan-ketentuan yang telah ditetapkan, baik dengan maupun tanpa bantuan dari yang berkepentingan, yang mencatat apa yang dimintakan untuk dimuat di dalamnya oleh yang berkepentingan, Akta otentik terutama memuat keterangan seorang pejabat, yang menerangkan apa yang dilakukannya dan dilihatnya dihadapannya.

Di dalam HIR akta otentik diatur dalam Pasal 165 (Pasal 1868 Kitab Undang-undang Hukum Perdata) yang berbunyi sebagai berikut; "akta otentik yaitu suatu akta yang dibuat oleh atau dihadapan pejabat yang diberi wewenang untuk itu, merupakan bukti yang lengkap antara para pihak dan para ahli warisnya dan mereka yang mendapat hak dari padanya tentang yang tercantum didalamnya dan bahkan tentang yang tercantum di dalamnya sebagai pemberitahuan belaka, akan tetapi yang terakhir ini hanyalah sepanjang yang diberitahukan itu erat hubungannya dengan pokok daripada akta".

Tugas Notaris adalah membuat akta, menyimpannya dan menerbitkan grosse, membuat salinan dan ringkasannya, Notaris hanya mengkonstantir apa yang terjadi dan apa yang dilihat, didalamnya serta mencatatnya dalam akta (Pasal 1 Peraturan Jabatan Notaris, S.1860 Nomor 3$)^{8}$ Adapun yang dimaksud Akta
Otentik yang termuat dalam Pasal 1808 Kitab Undang-undang Hukum Perdata, yaitu : ${ }^{9}$

a. Dibuat dalam bentuk yang ditentukan Undang-undang.

b. Dibuat oleh Pejabat Umum.

c. Pejabat umum tersebut berwenang dimana akta itu dibuat.

Kedudukan Notaris sebagai Pejabat Umum memberikan wewenang kepada Notaris untuk dapat membuat akta-akta otentik. Berbeda halnya dengan pegawai Negeri karena meskipun mereka adalah pejabat dan mempunyai tugas untuk meleyani kepentingan umum, tetapi bukan merupakan Pejabat Umum seperti yang dimaksud dalam Pasal 1868 Kitab Undang-undang Hukum Perdata. Notaris bukan pegawai negeri sebagaimana yang dimaksud dalam peraturan kepegawaian. Notaris dalam hal ini tidak menerima gaji, melainkan menerima honorarium dari kliennya.

Sebelum menjalankan jabatannya, Notaris harus disumpah terlebih dahulu. Hal ini membawa konsekuensi bahwa dalam menjalankan jabatannya. Hal ini sebenarnya menegaskan bahwa jabatan sebagai Notaris haruslah independen, dalam arti kata tidak memihak kepada pihak-pihak tersebut, sehingga Notaris menjadi jabatan kepercayaan.

Selain jabatan kepercayaan, Notaris juga berperan dalam melayani kepentingan umum serta mengatur secara tertulis dan otentik hubunganhubungan hukum antara pihak yang secara mufakat meminta jasa Notaris, maka Notaris dituntut mempunyai pengetahuan yang luas serta tanggung

${ }^{8}$ Sudikno Mertokusumo, Op. Cit, h. 3

${ }^{9}$ R.Subekti, , Op.Cit, h. 59. 
jawab yang besar terhadap segala hal yang telah dilakukannya.

\section{BAB III. SIMPULAN DAN SARAN}

Dari uaraian yang telah penulis kemukakan diatas, maka penulis sampaikan beberapa simpulan dan saran sebagai berikut:

\subsection{Simpulan}

1. Pengetahuan masyarakat Desa mengenai pentingya pendaftaran tanah sangatlah kurang terbukti dengan banyak peristiwa hukum perdata yang penting hanya dibuktikan dengan kesaksian dari beberapa orang saksi dari tetangga, teman sekampung atupun Kepala Desa.

2. Masyarakat sebagaian besar belum mengenal notaris. Bagi masyarakat desa yang melakukan peristiwa hukum perdata biasanya hanya dibantu oleh perangkat desa saja. Keberadaan kantor notaries juga menjadi suatu kendala atau hambatan bagi masyarakat Desa yang memerlukan bantuan notaries dalam membuat akta otentik, mereka harus menempuh jarak yang cukup jauh.

\subsection{Saran}

Diharapkan peran pemerintah dalam memfasilitasi masyarakat dipedesaan mengenai mempermudah masyarakat pedesaan dalam mendapatkan layanan jasa dari Notaris. Perlunya penyuluhan hukum yang terus menerus dan berkelanjutan mengenai Pentingnya Akata Otentik dalam Pembuktian.

\section{DAFTAR PUSTAKA}

Asshiddiqie, Jimly dan Ali Safa'at, 2006, Teori Hans Kelsen Tentang Hukum, Setjen dan Kepaniteraan Mahkamah Konstitusi Republik Indonesia, Jakarta.

Mertokusumo, Sudikno, 1999, Mengenal Hukum suatu Pengantar, Liberty, Yogyakarta.

, Sudikno, 2006, Hukum Acara Perdata Indonesia, Liberty, Yogyakarta.

Notodirejo. R, Soegondo 1982, Hukum Notariat Di Indonesia, Rajawali, Jakarta.

Subekti, R. 2001, Hukum Pembuktian, Pradinya Paramita, Jakarta.

Tresna, R. 1996, Komentar HIR, Pradaya paramita,Jakarta. 